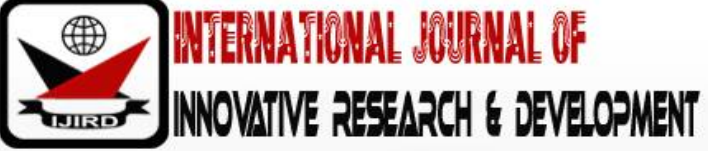

ISSN 2278 - 0211 (Online)

\section{An overview of groundwater and sanitation challenges in Kisumu City, Kenya.}

\author{
Japhet Rugendo Kanoti \\ Lecturer, Department of Geology, University of Nairobi, Kenya \\ Daniel Olago \\ Professor, Department of Geology; University of Nairobi, Kenya \\ Norbert Opiyo \\ Professor, Department of Geology; University of Nairobi, Kenya \\ Christopher Nyamai \\ Professor, Department of Geology; University of Nairobi, Kenya
}

\begin{abstract}
:
The sub-surface is used in most parts of Africa as a repository of human waste and as a source of groundwater through pit latrines and shallow wells respectively. The wells provide freshwater to millions of people in Africa who are either not connected to the piped water or have intermittent supplies. These shallow wells are hand dug and therefore are mostly less than 20 meters in depth. This same sub-surface environment is also used as a repository of human waste through pit latrines. The water points and the sanitation facilities are mostly located close to each other. This study aimed at appraising the groundwater and sanitation challenges based on a rapid survey, sampling, interviews, existing literature review and historical borehole data in Kisumu city, Kenya. Previous studies in the area have shown that the number of shallow wells, city buildings, density of unimproved pit latrines and sanitary risks have increased tremendously between 1999 and 2019. Most of the wells are shallow and therefore prone to contamination by pollutants. Fluoride and chloride content in most boreholes are above the recommended WHO maximum values and the local KEBS standards. The study confirmed that the main water and sanitation challenges in Kisumu are poor and deteriorating water quality, poor waste disposal management systems and poor sanitation services. There is need for the introduction of new and sustainable groundwater approaches supported by scientific models and involving all stakeholders. Current deficiencies in the provision of adequate water and dignified sanitation to the poor in Kisumu can be remedied through improved knowledge on shallow aquifer dynamics and innovative research. It was noted that apart from the donor agencies and multi-national NGOs, the private investors are unwilling to invest in water projects in Kisumu due in part to government legislation that constrains the cost that may be levied on water
\end{abstract}

Keywords: Groundwater, shallow wells, water pollution, sanitation, Kisumu, Kenya

\section{Introduction}

Billions of people worldwide lack access to water and sanitation facilities(Amoyaw, Boamah, Osei, Luginaah, \& Boateng, 2015; Cassivi, Dorea, Johnston, \& Waygood, 2018; Eagin \& Graham, 2014; Kunnuji, 2014; Mahama, Anaman, \& Osei-Akoto, 2014; Mariwah, Amo-Adjei, \& Anima, 2017). This scenario is expected to escalate due to climate changes and increase in population(Carvalho Resende et al., 2018; Cassivi et al., 2018). It is with this vision that United Nation formulated Sustainable Development Goal number 6 that laid strategies for ensuring access to safe water by all by 2030(UN-Water, 2018; UNICEF, 2017). Surface water sources are slowly diminishing due to a myriad of factors that include climate variability, land use changes, increased demands by various sectors and urbanization(Conti \& Gupta, 2016; Graham \& Polizzotto, 2013; Nijsten, Christelis, Villholth, Braune, \& Gaye, 2018; Opisa, Odiere, Jura, Karanja, \& Mwinzi, 2012; Opisa et al., 2012; Thompson et al., 2012). Groundwater is therefore the current target in most parts of the world (Carvalho Resende et al., 2018; Taylor, Favreau, Scanlon, \& Villholth, 2019). However, development of groundwater water supply system is expensive and the immediate option in most developing countries is groundwater development through individual or communal shallow wells.

Worldwide, the rural to urban migration phenomena has tremendously increased as people move to towns in search of opportunities and good life(Amrevurayire, E. O., \& Ojeh, 2016; Gollopeni, 2015; Lal, Selod, \& Shalizi, 2006; Saracoglu \& Roe, 2004).The global urban population has rapidly grown since 1950from 751 million to about 4.2 billion in 2018. Asia, despite being less urbanized than most other regions today, is home to $54 \%$ of the world's urban population. Europe and Africa urban areas host $13 \%$ each of the global urban population(WHO/ Unicef (JMP), 2017).

The rapid growth in urban population is however unmatched by growth in essential services. Access to adequate and safe water in urban areas is below $50 \%$ and is expected to worsen with climate variability and demands. Sanitation services performance is worse, currently the coverage standing at less than $20 \%$. There are also disparities within the 
urban areas with informal settlements coverage in both the water coverage and sanitation services. In informal settlements of most developing countries' urban areas, the population rely on water from shallow wells or vendors selling water from unknown sources and quality (Lapworth, Nkhuwa, Pedley, \& Stuart, 2017; Wright, Cronin, Pedley, \& Gundry, 2013). These informal settlements are always not served by the main sewerage system and therefore rely on on-site sanitation(Amjad, Kayser, \& Meier, 2014; Mahama et al., 2014; Whitford, Smith, \& Mandawat, 2010). This form of sanitation is hazardous and leads to contamination of groundwater and the environment in general. According to the WHO-UNICEF report on the progress on sanitation and drinking-water 2017 update, almost a third (39\%) of the world population relied on unimproved sanitation facilities, while 15\% continued to defecate in the open(WHO/ Unicef (JMP), 2017).

\subsection{Location, Water Resources and Climate}

Kisumu County is one of the 47 Counties in Kenya. It is situated within longitudes $33^{\circ} 20^{\prime} \mathrm{E}$ and $35^{\circ} 20^{\prime} \mathrm{E}$ and latitudes $0^{\circ} 20^{\prime}$ South and $0^{\circ} 50^{\prime}$ South (County Government of Kisumu, 2018). The total land area is $2086 \mathrm{~km}^{2}$ and about $567 \mathrm{~km}^{2}$ is covered by water. Kisumu is situated on the shores of Lake Victoria, the third largest freshwater lake in the world. Due to poor investment in the water sector, only a fraction of the city's water demand is met through surface water works. The main water treatment works are situated in Dunga, on the shore of Lake Victoria. Massive pumps are used to lift water from Lake Victoria to the treatment plant. The second source of water is the Kajulu gravity water intake along R. Kajulu. The alternative sources of water are from shallow wells and a number of boreholes constructed by the communities and the donor agencies. However, this alternative has its own challenges ranging from vulnerability to contamination, over-abstraction and depletion.

The climate is generally warm with minimal monthly variation in temperatures between $23^{\circ} \mathrm{C}$ and $33^{\circ} \mathrm{C}$ throughout the year. The rainfall is determined by a modified equatorial climate characterized by long rains (March to May) and short rains (September to November). The average annual rainfall varies from 1000-1800mm during the long rains and 450-600mm during the short rains. The altitude in the County varies from 1,144 meters above the sea level on the plains to 1,525 meters above sea level in the Maseno and Lower Nyakach areas. The variation in elevation and presence of Lake Victoria greatly influences temperatures and rainfall.

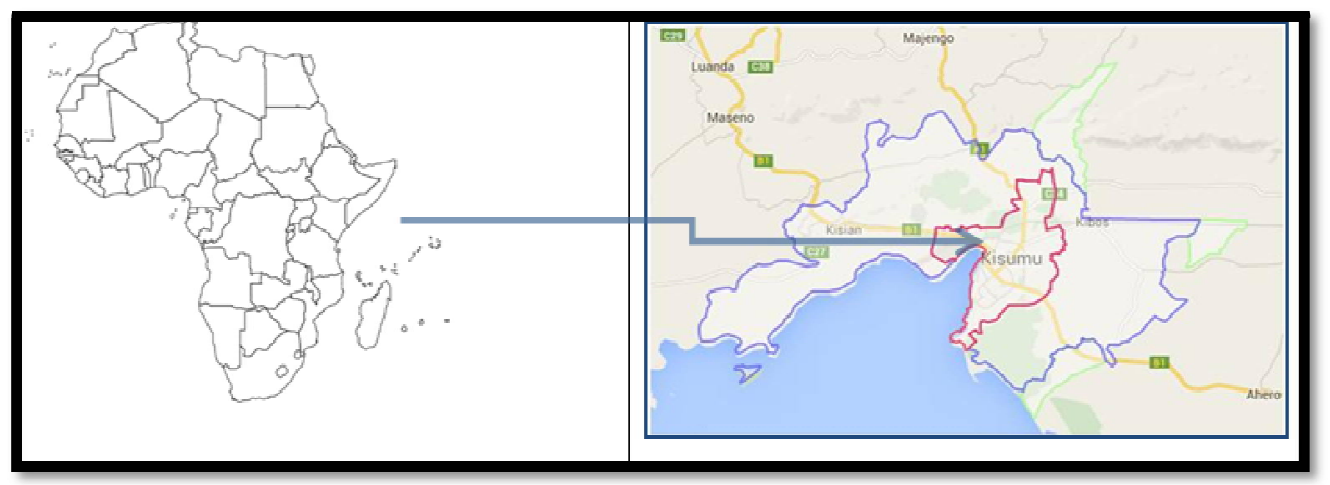

Figure 1: Location of the Study Area

\section{Objectives}

Accurate information on the spatial temporal occurrence of water resources is needed for proper and sustainable management of the resources. This information is most of the not available to the policy makers. This study collected information on the available water and sanitation data for Kisumu and transformed it into information. Therefore, the main objective of the study was to synthesis a preliminary overview of water and sanitation systems in Kisumu. This snap shot report summarizes the current scenario and forms a baseline for further studies in the area.

\section{Materials and methods}

A synthesis of existing groundwater records and a rapid mapping and interviews with the key stakeholders in the water sector to determine the main water and sanitation problems and challenges was undertaken in June 2015. The reconnaissance survey was also undertaken to appraise the regional geology and map existing water points and sanitation facilities with a view of getting baseline scenario. The examination of past groundwater quality records was also used as a baseline for water quality and rapid field studies of present water quality undertaken to determine changes over time.

\section{Results}

\subsection{Geology of the Study Area}

The oldest rocks in the Western Kenya are of Precambrian age. They are represented by the Basement System; the Nyanzian System and the Bukoban System. The Bukoban System rests unconformably on the Nyanzian which in turn overlies the Basement. During the considerable lapse of time between the deposition of the Bukoban System and the Tertiary era, folding and faulting took place and there were intrusions of dolerite into the Bukoban and Nyanzian rocks (Binge, 1962). In Kisumu area the rocks range from early Precambrian (2,200 million years) to Quaternary (2 million years)(Opiyo-Akech, 1988). However, between the early Precambrian and the Tertiary (65-2 million) there is a geological 
hiatus. There is no evidence of sedimentation between rocks of these two ages and this can be interpreted as due to absence of sedimentation or complete erosion of sediments deposited during this time span.

The main geological feature in the Kisumu area is the Kavirondo Rift(Pulfrey,1952). This rift branches from the main north-south orientated East African Rift Valley System(Mboya, 1983). It has an ENE-WSW direction. The formation of the rift involved two stages: a stage of down warping related to the formation of a shallow basin during the Miocene (22 to 6 million years) and stage of rift faulting during the Pliocene (6 to 2 million years) to Pleistocene (2 to 0.01 million years). The faulting has allowed the accumulation of Pleistocene sediments and possibly tuffs of a vast thickness. These sediments and tuffs are now covered by alluvial material. Tertiary faulting was accompanied by sheet eruptions of phonolitic lavas which are found north and north-west of Kisumu Town.

\subsection{Hydrogeology of the Study Area}

The area east of Kisumu city is dominated by a sedimentary plain (Kano plains) that formed during Pleistocene. It is postulated that the major factors that influenced the sedimentation were; a) The supply of different types of sediments by rivers depositing gravel and sands during periods of high discharge, and. clay and silt during periods of low discharge and b) the development of the Kavirondo Rift Valley which controlled the hydraulic gradient of the rivers and the deposition environment (land or lake). The sediments fine upward in the lithological section as a result of gradual filling up of the Rift Basin. They are therefore relatively coarse in the eastern part of the Kavirondo Rift Valley. The boreholes located in these sediments are very productive. The mean depth of the boreholes is about $90 \mathrm{~m}$ and average borehole yield is about $10 \mathrm{~m}^{3} / \mathrm{hr}$.

In areas where the geology is dominated by successions of volcanic rocks, groundwater is found in erosion layers that occur between successive lava outflows, in tunnels formed during cooling of the lava, or in buried river channels. However, it remains unclear whether the and esite and phonolites series are built up by several individual flows and/ or whether the erosional periods were long enough. Water bearing zone occur at the contact between the lava flow and the Precambrian rocks, at depths of over $300 \mathrm{~m}$. The contact consists of the Miocene limestone and bedded tuffs resting on gneisses of the sub-Miocene peneplain. Fault zones also have high groundwater prospects.

Groundwater within the Precambrian metamorphic rocks areas are usually found within the weathered regolith and the fractured areas. The Precambrian terrain topography (sub-Miocene surface) is of utmost importance in groundwater exploration in such terrains. Weathering is deepest in the areas which were low (syncline if the surface is folded). Feldspars within the Basement is expected to be rather clayey (high porosity, but low permeability). The underlying layer consist of less weathered, partly altered rock which usually has higher permeability. This layer is relatively thin or absent in the slopes and hilltops.

\subsubsection{Current Water and Sanitation Scenario and Predictions in Kisumu}

There is substantial uncertainty concerning the renewability, accessibility and management of groundwater resources in sub-Sahara Africa Over the past decade, the sub-Saharan Africa has experiences severe change of climate variables including extreme droughts, extreme rainfalls and extreme temperatures(IPCC, 2018). One effect of this variability in climate is the impacts on groundwater quality and quantity. The related consequences and shocks take a long time to subside and are mostly associated with poor community health and infectious waterborne diseases. Short-term changes in groundwater quality in Kisumu have been reported by various researchers (Lapworth, Nkhuwa, Okotto-Okotto, et al., 2017; Okotto, Okotto-Okotto, Price, Pedley, \& Wright, 2015). However, long-term impacts on groundwater quality in deep wells and boreholes where there is a lag of years between injection of contaminant from the surface and its impacts on groundwater quality have attracted less attention. Studies have shown that the number of shallow wells, city buildings, density of unimproved pit latrines and sanitary risks have increased tremendously between 1999 and 2015 (OkottoOkotto et al., 2015).

The water coverage in Kisumu is below 50\% and sewerage 8\% (AFW, 2014). Therefore, access to safe and affordable water, and dignified sanitation are the main challenges facing the residents of Kisumu. The majority of residents get water from numerous self-supply wells because piped water is either intermittent or unavailable. Due to low sewerage coverage, most low-income residents use self-constructed pit latrines for sanitation.

\subsubsection{Main Water Sources}

The main water sources in Kisumu are L. Victoria, shallow wells, unprotected springs, boreholes and roof catchment systems. During the dry season, some of the water sources run dry forcing people to take longer time to fetch water. Women and children specially spend more time in search of water than men and boys.Thisconsumesalotofproductivetimeandschoolinghoursleadingtopooreducationforgirlsandreducedfamilyincome.Over $40 \%$ of households in low income settlements spend about 20 minutes to access water, and some areas over one hour (Figure 2). 


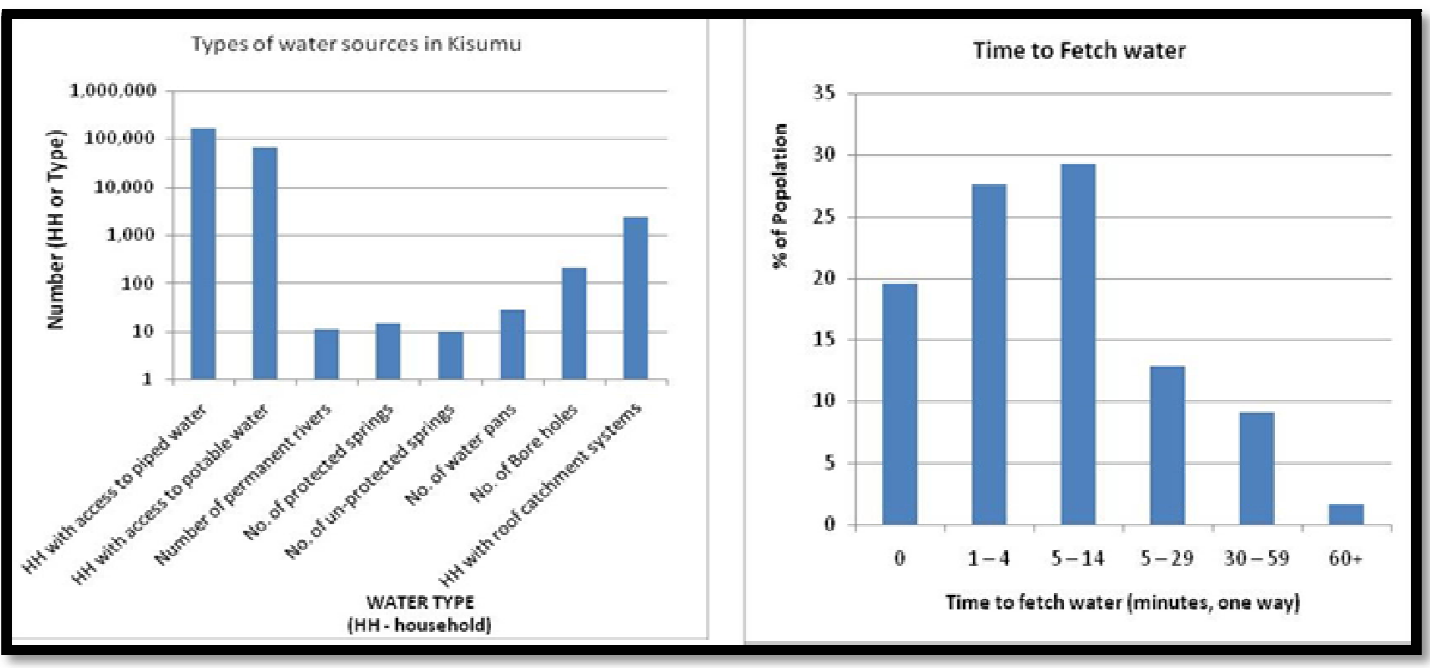

Figure 2: Type Of Water Sources in Kisumu (Left) and Time Taken to Water Point (Right)

The alternative water sources in most areas is untreated and poses a health risk when used for drinking.

\subsubsection{Bacteriological Water Quality}

We conducted thermal tolerant coliform test with a portable kit and confirmed that the alternative water sources were contaminated. Surface water was heavily loaded with TTCs and requires treatment before it is can be consumed. Shallow wells and springs are easily contaminated by pit latrines, grey water and surface runoff during rains. Shallow wells situated in close proximity to the pit latrines are readily contaminable and contributes to dangerous outbreaks of diseases such as diarrhea, cholera, typhoid, dysentery and malaria in the region(Maoulidi, 2015).

\subsubsection{Water Chemistry}

The interaction between the rocks and water modifies the chemistry of water overtime. The table 1 below gives data for groundwater samples collected in Kisumu. Routine water quality monitoring is rarely done and data available is from the borehole completion records. Water quality data is scarce in Kenya partly due to high cost of analysis and partly due weak enforcement of water regulations.

\begin{tabular}{|c|c|c|c|c|c|c|c|c|c|c|c|c|c|c|}
\hline STN CODE & pH & COND & Fe & Mn & Ca & Mg & Na & K & Cl & F & SO4 & HCO3 & TDS & NO3 \\
\hline C-11508 & 6.5 & 480 & 0.07 & 0.07 & 36 & 9.1 & 55.5 & 12 & 21 & 1 & 10 & 224 & 328 & 1.7 \\
\hline C-11947 & 7 & 600 & 4.3 & 0.7 & 26 & 14.4 & 96.1 & 28.9 & 32.5 & 0.4 & 70 & 250 & 420 & 0 \\
\hline C-12126 & 6.4 & 270 & 0.02 & 0.01 & 28 & 15.4 & 68.04 & 15.01 & 5 & 0.2 & 12 & 148 & 190 & 0 \\
\hline C-13702 & 8.3 & 680 & 1 & 0.1 & 16 & 2.4 & 148.9 & 8.3 & 30 & 4 & 20 & 325 & 480 & 0 \\
\hline C-13703 & 8.2 & 1400 & 0 & 0.2 & 40 & 6 & 252.8 & 28 & 110 & 4 & 70 & 500 & 950 & 0 \\
\hline C-2873 & 8.5 & 325 & 0.2 & 0 & 36 & 13 & 17 & 2 & 5 & 0.8 & 8 & 146 & 195 & 0 \\
\hline C-2874 & 8.6 & 381 & 0.2 & 0 & 32 & 17 & 28 & 3 & 9 & 1.1 & 7 & 210 & 228 & 3.2 \\
\hline C-2875 & 7.9 & 680 & 0 & 0 & 68 & 17 & 82 & 1 & 16 & 1.9 & 13 & 378 & 408 & 11.1 \\
\hline C-3330 & 8.2 & 442 & 0 & 0 & 36 & 22 & 39 & 5 & 3 & 1 & 3 & 281 & 265 & 0 \\
\hline C-3401 & 7.8 & 998 & 0 & 0 & 51 & 6 & 172 & 4 & 24 & 4 & 28 & 537 & 598 & 1.1 \\
\hline C-3435 & 8.5 & 875 & 0 & 0 & 43 & 6 & 147 & 6 & 21 & 4.6 & 24 & 461 & 525 & 6.6 \\
\hline C-3550 & 8.4 & 382 & 0 & 1 & 43 & 5 & 29 & 5 & 9 & 1.1 & 5 & 185 & 229 & 0 \\
\hline C-3734 & 7.4 & 675 & 0 & 0 & 85 & 16 & 58 & 3 & 34 & 1.3 & 33 & 283 & 405 & 44.3 \\
\hline C-3806 & 7 & 650 & 0.6 & 0 & 71 & 27 & 28 & 10 & 8 & 0.6 & 28 & 459 & 390 & 2.2 \\
\hline C-3817 & 7.4 & 758 & 0.3 & 0 & 50 & 12 & 65 & 14 & 26 & 1.8 & 17 & 329 & 455 & 5.5 \\
\hline C-4145 & 7.7 & 1400 & 0.2 & 0.6 & 45 & 3.8 & 153 & 66 & 31 & 4 & 15 & 622 & 840 & 0 \\
\hline C-4246 & 8.3 & 1100 & 0.1 & 0.1 & 84 & 44 & 53 & 6 & 35 & 2 & 25.6 & 56 & 66 & 0 \\
\hline C-8062 & 8.3 & 1140 & 2 & 0.1 & 49 & 7 & 19 & 4 & 33 & 2 & 103 & 514 & 684 & 0 \\
\hline
\end{tabular}

Table 1: Chemical Data of Selected Boreholes in Kisumu the Units Are Mg/ L

From the water chemistry perspectives, groundwater is of good quality. However, fluoride levels exceed the WHO limits in a number of borehole (World health organisation, 2017). The recommended maximum is $1.5 \mathrm{mg} / \mathrm{l}$. Concentrations above this value carry an increasing risk of dental fluorosis, and much higher concentrations lead to skeletal fluorosis. The nitrate levels are within the WHO limits (nitrate max $10 \mathrm{mg} / \mathrm{L}$ ). Presence of nitrate is an indicator of contamination either through grey water or sanitation. 


\subsubsection{Liquid and Solid Waste Disposal}

The waste disposal in Kisumu is not well organized - the refuse collection efficiency is less than $20 \%$. Wealthier estates have their refuse collected whereas slums are largely neglected and rely on on-site burning and open public dumping site along the streets. The city has about $10 \%$ sewerage coverage and the slum dwellers rely on pit latrines that are overused and not adequately maintained (UN-Habitant, 2006).

\begin{tabular}{|c|c|c|}
\hline Facility & Percentage & Number \\
\hline Traditional pit latrine & 55.01 & 4758 \\
\hline Improved pit latrine (air vent, proper superstructure) & 19.99 & 1729 \\
\hline Toilet linked to sewer & 10.72 & 927 \\
\hline Other sanitation facility & 5.94 & 514 \\
\hline Ventilated Improved Pit latrine (VIP) (vent pipe, fly screen) & 4.06 & 351 \\
\hline Pour flush toilets & 1.45 & 125 \\
\hline Flying toilets & 1.23 & 106 \\
\hline Toilet linked to septic tank & 1.19 & 103 \\
\hline Open defecation (bush, drain, etc.) & 0.41 & 35 \\
\hline
\end{tabular}

Table 2: Main Sanitation Facilities or Practices Used by Households in Obunga Informal Settlements

Traditional pit latrines are preferred in all informal settlements in Kisumu because they are cheap to dig and construct. A number of households do not have sanitation facilities and use flying toilets or open defection along drains, or disused railway line. The face al matter is washed into the rivers and ultimately into Lake Victoria. The County Government of Kisumu and NGOs are constructing communal toilets and open defecation may soon be a thing of the past

The solid waste disposal is not well organized and heaps of uncollected garbage are sometime found along the road sides. The main dump site is at the center of the town though plans are underway to relocate it. The dumpsite is next to residential and commercial houses and cause health problems and intolerable living conditions. Though the Government of Kenya has banned use of polythene papers, plastic bottles are a nuisance and blocks storm water drains during heavy rains. Slums are the hardest hit as they have no access to safe drinking water, sanitation or sewerage facilities, and waste collection is almost non-existent.

The main sewage treatment plant in Kisumu is the Kisat Conventional Sewage Treatment Plant that was built in 1958. There are in addition three main private industrial wastewater treatment plants, two of which are pre-treatment facilities only, with just one a full treatment plant. The three are Kisumu molasses, Kisumu cotton mills and the Kenya breweries. Kisumu molasses is a full treatment plant. Nyalenda Waste Stabilization Pond serves the eastern part of the city and is located adjacent to the Nyalenda low-income area. This plant has not been properly maintained and is not fully operational (LVSWSB, 2008).

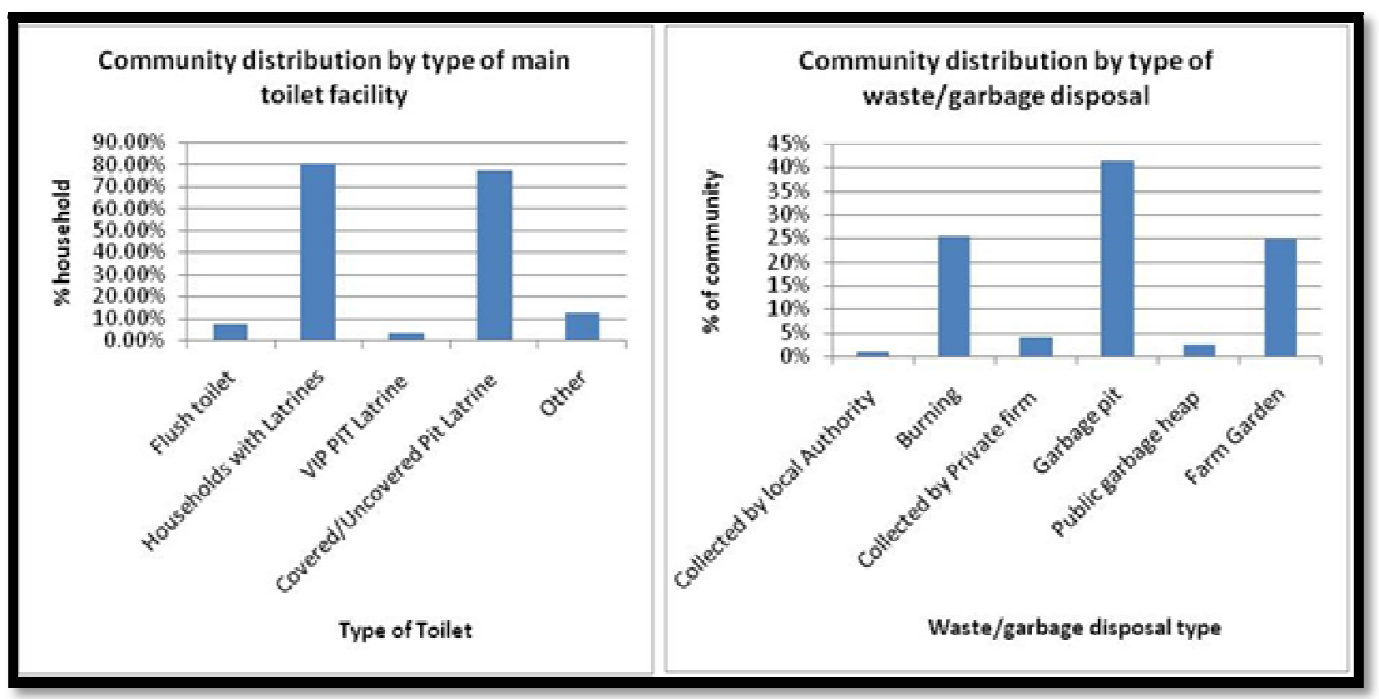

Figure 3: Community Distribution by Type of Main Toilet (Left) and Waste Disposal Facilities (Right)

The amount of garbage collected by the County Government in the low-income estates is low (figure 2) and majority use garbage pits within their compounds or on road reserves. The preferred toilet in Kisumu is the pit latrine constituting over $80 \%$ of households,

\subsubsection{Conclusions}

Provision of affordable and safe water is an international and national priority. Water resources in Kenya generally have been mismanaged through unsustainable water and land use policies, weak water allocation practices and poorly funded water institutions. This survey and existing literature reviews have demonstrated that Kisumu groundwater 
quality is threatened by both natural and anthropogenic processes. The situation is likely to worsen in future if no action is taken. The low-income consumers are dependent on such unsafe waters.

Kisumu suffers water shortages due to many causes. They include poor surface water quality, low investment in the water sector, high non-water revenue, poor waste disposal management and poor sanitation services. Other factors include hydrogeological constraints and areal urban spread population growth. The demand for land to construct houses has led to the expansion of city boundaries to once protected areas. The shores of Lake Victoria have been encroached as well as the hilly escarpments. Environmental degradation is evident in Kisumu and the surrounding areas. Deforestation and settlement on high gradient areas almost result into increased runoff, which has negative implications on recharge and flash floods.

The current deficiencies in the provision of water and dignified sanitation to the poor in Kisumu can be enhanced through improved knowledge and innovative and affordable services. There is need for the introduction of new development approach that involves all stakeholders. Apart from the donor agencies and multi-national NGOs, the private investors do not show willingness to invest in water projects in Kenya. This probably could be attributed to the fact that water is viewed as a human right and investors therefore feel that the government may interfere in water business.

\section{Acknowledgement}

This paper is an output from the AfriWatSan project funded by The Royal Society Africa Capacity Building Initiative and the UK Department for International Development (DFID) (Grant Ref. AQ140023). The views expressed and information contained in it are not necessarily those of or endorsed by the Royal Society or DFID, which can accept no responsibility for such views or information or for any reliance placed on them.

\section{References}

i. AFW. (2014). Un-sewered Sanitation Improvements for the Urban-Poor. African Water Facility publication. Online. Retrieved https:/ / www.africanwaterfacility.org/fileadmin/ uploads/awf/ Publications/Urban_Sanitation_Portfolio_Review.pdf

ii. Amjad, U. Q., Kayser, G., \& Meier, B. M. (2014). Rights-based indicators regarding non-discrimination and equity in access to water and sanitation. Journal of Water, Sanitation and Hygiene for Development, 4(1), 182-187. https:/ / doi.org/ 10.2166/ washdev.2013.041

iii. Amoyaw, J., Boamah, S., Osei, L., Luginaah, I., \& Boateng, G. O. (2015). The paradox of water accessibility: understanding the temporal and spatial dimensions of access to improved water sources in Rwanda. Journal of Water Sanitation and Hygiene for Development, washdev2015029. https:/ / doi.org/ 10.2166/ washdev.2015.029

iv. Amrevurayire, E. O., \& Ojeh, V. N. (2016). Consequences of Rural-Urban Migration on the Source Region of Ughievwen Clan Delta State Nigeria. Uropean Journal of Geography, 7(3), 42-57.

v. Binge, W. (1962). Geology of Kericho area. Geological Survey of Kenya, Report No. 42

vi. Carvalho Resende, T., Longuevergne, L., Gurdak, J. J., Leblanc, M., Favreau, G., Ansems, N., ... Aureli, A. (2018). Assessment of the impacts of climate variability on total water storage across Africa: implications for groundwater resources management. Hydrogeology Journal. https:/ / doi.org/ 10.1007/ s10040-018-1864-5

vii. Cassivi, A., Dorea, C. C., Johnston, R., \& Waygood, E. O. D. (2018). Access to drinking water: Time matters. Journal of Water and Health, 16(4), 661-666. https:/ / doi.org/ 10.2166/ wh.2018.009

viii. Conti, K. I., \& Gupta, J. (2016). Global governance principles for the sustainable development of groundwater resources. International Environmental Agreements: Politics, Law and Economics, 16(6), 849-871. https:/ / doi.org/ 10.1007/ s10784-015-9316-3

ix. County Government of Kisumu. (2018). Kisumu county integrated development plan II, 2018-2022. Online. Retrieved from https:// roggkenya.org/ wp-content/ uploads/ Kisumu_CIDP_2018-2022_County-IntegratedDevelopment-Plan.pdf

x. Eagin, B., \& Graham, J. P. (2014). A study of water and sanitation access trends in Peru: where do inequities persist? Journal of Water, Sanitation and Hygiene for Development, 4(3), 499-508. https:/ / doi.org/ 10.2166/ washdev.2014.113

xi. Gollopeni, B. (2015). Rural Urban Migration in Kosovo. International Journal of Business and Social Science, 6(91), 674-682.

xii. Graham, J. P., \& Polizzotto, M. L. (2013). Pit latrines and their impacts on groundwater quality: A systematic review. Environmental Health Perspectives, 121(5), 521-530. https:/ / doi.org/ 10.1289/ ehp.1206028

xiii. IPCC. (2018). Global warming of 1.5 C. Online. Retrieved from https:/ / www.ipcc.ch/ sr15/

xiv. Kunnuji, M. (2014). Spatial variations in access to improved sanitation and water in Lagos state. Journal of Water, Sanitation and Hygiene for Development, 4(4), 612-619. https:/ / doi.org/ 10.2166/ washdev.2014.102

xv. Lal, S. V, Selod, H., \& Shalizi, Z. (2006). Rural-urban migration in Developing countries: A survey theoretical predictions and empirical findings. World. https:/ / doi.org/ http:/ / dx.doi.org/ 10.1596/ 1813-9450-3915

xvi. Lapworth, D. J., Nkhuwa, D. C. W., Okotto-Okotto, J., Pedley, S., Stuart, M. E., Tijani, M. N., \& Wright, J. (2017). Urban groundwater quality in sub-Saharan Africa: current status and implications for water security and public health. Hydrogeology Journal, 1093-1116. https:/ / doi.org/ 10.1007/ s10040-016-1516-6

xvii. Lapworth, D. J., Nkhuwa, D. C. W., Pedley, S., \& Stuart, M. E. (2017). Urban groundwater quality in sub-Saharan Africa : current status and implications for water security and public health, 1093-1116. https:// doi.org/ 10.1007/ s10040-016-1516-6 
xviii. Mahama, A. M., Anaman, K. A., \& Osei-Akoto, I. (2014). Factors influencing householders' access to improved water in low-income urban areas of Accra, Ghana. Journal of Water and Health, 12(2), 318-331. https:/ / doi.org/ 10.2166/ wh.2014.149

xix. Maoulidi, M. (2015). Water and sanitation needs assessment for Kisumu City , Kenya.MCI Social Sector Research

xx. Mariwah, S., Amo-Adjei, J., \& Anima, P. (2017). What has poverty got to do with it? Analysis of household access to improved sanitation in Ghana. Journal of Water Sanitation and Hygiene for Development, 7(1), 129-139. https:/ / doi.org/ 10.2166/ washdev.2017.101

xxi. Mboya, B. (1983). The genesis and tectonics of the N.E. Nyanza rift valley, Kenya. Journal of African Earth Sciences (1983), 1(3-4), 315-320. https:/ / doi.org/ Doi: 10.1016/ s0731-7247(83)80016-0

xxii. Nijsten, G. J., Christelis, G., Villholth, K. G., Braune, E., \& Gaye, C. B. (2018). Transboundary aquifers of Africa: Review of the current state of knowledge and progress towards sustainable development and management. Journal of Hydrology: Regional Studies, (March), 1-14. https:/ doi.org/ 10.1016/ j.ejrh.2018.03.004

xxiii. Okotto, L., Okotto-Okotto, J., Price, H., Pedley, S., \& Wright, J. (2015). Socio-economic aspects of domestic groundwater consumption, vending and use in Kisumu, Kenya. Applied Geography, 58, 189-197. https:// doi.org/ 10.1016/ j.apgeog.2015.02.009

xxiv. Opisa, S., Odiere, M. R., Jura, W. G. Z. O., Karanja, D. M. S., \& Mwinzi, P. N. M. (2012). Faecal contamination of public water sources in informal settlements of Kisumu City, western Kenya. Water Science and Technology, 66(12), 26742681. https:/ / doi.org/ 10.2166/ wst.2012.503

xxv. Opiyo-Akech, N. (1988). Geology and geochemistry of the late Archaean greenstone associations, Maseno area, Kenya.PhD thesis, University of Leicester.

xxvi. Pulfrey, W. (1952). Geology of the Kisumu District. Geological Survey of Kenya, Report No. 21

xxvii. Saracoglu, S., \& Roe, T. L. (2004). Rural-Urban Migration and Economic Growth in Developing Countries. 7th Annual Conference on Global Economic Analysis, (June 2014). Retrieved from https:/ / www.gtap.agecon.purdue.edu/ resources/ download/ 1734.pdf

xxviii. Taylor, R. G., Favreau, G., Scanlon, B. R., \& Villholth, K. G. (2019). Topical Collection: Determining groundwater sustainability from long-term piezometry in Sub-Saharan Africa. Hydrogeology Journal, 2013-2016. https:// doi.org/ 10.1007/ s10040-019-01946-9

xxix. Thompson, T., Fawell, J., Kunikane, S., Jackson, D., Appleyard, S., Callan, P., ... Kingston, P. (2012). Chemical safety of drinking-water: assessing priorities for risk management. Int. J. Environ. Stud., 69(6), 1-2. https:/ / doi.org/ 10.1080/ 00207233.2011.565947

xxx. UN-Habitant. (2006). 2006 Annual Report. United Nation Publication. Online. Retrieved from https:/ / unhabitat.org/ year/ 2006

xxxi. UN-Water. (2018). Nature-Based solutions for Water. The United Nations World Water Development Report 2018. Paris. Online. Retrieved from www.unwater.org/ .../ world-water-development-report-2018/

xxxii. UNICEF. (2017). Launch version July 12 Main report Progress on Drinking Water , Sanitation and Hygiene. Online. Retrieved fromwww.who.int/ .../ releases/ 2017/ launch-version-annexes-jmp-water-sanitation-hygiene.pdf

xxxiii. Whitford, A. B., Smith, H., \& Mandawat, A. (2010). Disparities in access to clean water and sanitation: Institutional causes. Water Policy, 12(SUPPL. 1), 155-176. https:/ / doi.org/ 10.2166/ wp.2010.019

xxxiv. WHO/ Unicef (JMP). (2017). Progress on Drinking Water, Sanitation and Hygiene. Online. Retrieved from https:// www.who.int/ water_sanitation_health/ .../jmp-2017/ en/

xxxv. World health organisation. (2017). Guidelines for drinking-water quality: fourth edition incorporating the first addendum.WHO Library Cataloguing-in-Publication Data. https:/ / doi.org/ 10.1016/ S1462-0758(00)00006-6

xxxvi. Wright, J. A., Cronin, A., Pedley, S., \& Gundry, S. W. (2013). A spatial analysis of pit latrine density and groundwater source contamination, 4261-4272. https:// doi.org/ 10.1007/ s10661-012-2866-8 